\title{
Krom (III) Klorür Tuzuna Maruz Kalan Saccharomyces cerevisiae’ nın Stres Yanıtı
}

\author{
Ebru ÇÖTELi ${ }^{1 *}$, Fikret KARATAŞ², Seher GÜR ${ }^{3}$ \\ ${ }^{1}$ Tıbbi Hizmetler ve Teknikler Bölümü, Sağlık Hizmetleri Meslek Yüksekokulu, Ahi Evran Üniversitesi, Kırşehir, \\ Türkiye \\ ${ }^{2}$ Kimya Bölümü, Fen Fakültesi, Fırat Üniversitesi, Elazığg, Türkiye \\ ${ }^{3}$ Biyoloji Bölümü, Fen Fakültesi, Fırat Üniversitesi, Elazığ, Türkiye \\ 111e.coteli@ahievran.edu.tr, ${ }^{2}$ fkaratas@firat.edu.tr, ${ }^{3}$ sgur@firat.edu.tr
}

(Geliș/Received: 04/05/2021;

Kabul/Accepted: 12/08/2021)

Öz: Son yıllardaki çalışmalar, mikroelementlerin yüksek yapılı organizmalar ile maya metabolizması üzerindeki etkilerine yoğunlaşmıştır. Bu çalışmada, Saccharomyces cerevisiae mikroorganizması iki farklı dozda (10 ve $40 \mu \mathrm{g} / \mathrm{mL}) \mathrm{krom}$ III klorür tuzuna 12,24 ve 36 saat boyunca maruz bırakılmıştır. Krom tuzuna maruz bırakılan maya örneklerine 10, 15 ve $20 \mu \mathrm{g} / \mathrm{mL}$ miktarlarında $\mathrm{C}$ vitamini eklenmiştir. Maya ve krom etkileşiminin mikroorganizmadaki bazı biyokimyasal parametrelere (A, E, C vitaminleri, Glutatyon, Malondialdehit) etkileri HPLC cihazı ile belirlenmiştir. Artan krom dozu ve süreye bağlı olarak mayaların hücre sayıları, GSH, A, E, C vitamini miktarları ve GSH/GSSG oranlarında azalma, GSSG ve MDA miktarlarında ise artmaların olduğu belirlenmiştir. Artan C vitamini dozuna bağlı olarak mayaların hücre sayıları, GSH, A, E, C vitamini miktarları ve GSH/GSSG oranında artma, GSSG ve MDA miktarlarında azalmaların olduğu gözlenmiştir. Sonuç olarak; kromun maya mikroorganizmasında serbest radikal oluşumunu artırdığı, değişik konsantrasyonlarda eklenen $\mathrm{C}$ vitamininin serbest radikal oluşumunu azalttığı sonucuna varılmıştır.

Anahtar kelimeler: Saccharomyces cerevisiae, Krom, Vitamin, Stres, Antioksidan parametreler.

\section{Response Stres of Saccharomyces cerevisiae Exposed to Chromium (III) Chloride Salt}

\begin{abstract}
Recent studies have focused on the effects of microelements on higher organisms and yeast metabolism. In this study, Saccharomyces cerevisiae microorganism was exposed to chromium III chloride salt at two different doses (10 and 40 $\mu \mathrm{g} / \mathrm{mL}$ ) for 12,24 and 36 hours. Vitamin $\mathrm{C}$ was added in amounts of 10,15 and $20 \mu \mathrm{g} / \mathrm{mL}$ to the yeast samples exposed to chromium salt. The effects of yeast and chromium interaction on some biochemical parameters (vitamins A, E, C, Glutathione, Malondialdehyde) in microorganisms were determined by HPLC device. It was determined that there was a decrease in the cell numbers of yeast, the amounts of GSH, A, E, C vitamins and GSH/GSSG ratios, an increase in the amounts of GSSG and MDA depending on the increasing chromium dose and time. It was observed that there was an increase in the cell numbers of yeast, the amounts of GSH, A, E, C vitamins and GSH/GSSG ratios, a decrease in the amount of GSSG and MDA depending on the increased dose of vitamin C. As a result; It was concluded that chromium increases the formation of free radicals in yeast microorganism, vitamin $\mathrm{C}$ added at different concentrations reduces the formation of free radicals.
\end{abstract}

Key words: Saccharomyces cerevisiae, Chromium, Vitamin, Stres, Antioxidant parameters.

\section{Giriş}

Mayalar tek hücreli mantarlar olup tomurcuklanma yoluyla çoğalırlar. Anaerobik koşullarda bile mayalar rahatlıkla gelişebilir. Bazı mantarlarda olduğu gibi, mayalar da asidik koşullara dayanıklıdır [1]. Mayalar en fazla alkol üretiminde, ekmek ve turşuların yapımında, vitaminler, gliserol, lipidlerin ve proteinlerin üretiminde [2-4], gıda, kimya, ilaç ve zirai alanlarda kullanılmaktadır [3-5]. Saccharomyces cerevisiae ekmek veya bira mayası olarak bilinmektedir [6]. S. cerevisiae vitaminler, aminoasitler, $\beta$-glukan gibi önemli maddeleri de içermektedir [7]. Maya hücrelerinin (S. cerevisiae) vitamin, protein, karbonhidrat, yağ ve mineral bakımından zengin olduğu için kozmetik alanında da çok faydalı olabileceği ileri sürülmektedir [8]. Mayalar fiziksel, kimyasal ve biyolojik strese maruz kalabilirler. Kimyasal stres faktörlerinden biri de metal iyonlarının stresidir. Krom canlılar için gerekli eser elementlerden biri olup, fazla miktarlarda alındığında toksik etki göstermektedir. Özellikle krom (VI), krom (III)'e göre daha toksiktir [9, 10].

Son zamanlarda mayalar biyoteknolojik çalışmalarda çok sık kullanılmaktadır. Özellikle biyosorpsiyon çalışmaları bunlardan birisidir. Çalışmada kullanılan S. cerevisiae' nın metal biyosorbsiyon çalışmalarında kullanıldığı bilinmektedir. Ancak günümüze kadar yapılan çalışmalarda, krom (III)’ un S. cerevisiae metabolizması üzerindeki bazı biyokimyasal parametrelere etkileri tam olarak açıklanamamıştır. Ayrıca maya

\footnotetext{
* Sorumlu yazar: e.coteli@,ahievran.edu.tr. Yazarların ORCID Numaras1: ${ }^{1}$ 0000-0002-9473-0914, ${ }^{2}$ 0000-0002-0884-027X, ${ }^{3} 0000-0003-$ $0081-5990$
} 
gelişme ortamına antioksidan özelliği bilinen C vitamininden değişik konsantrasyonlarda eklenilerek, krom metali ve C vitamininin S. cerevisiae' daki bu biyokimyasal parametreler (A, E, C vitamini, Malondialdehit, Glutatyon) üzerine etkilerinin araştırılması amaçlanmıştır.

\section{Materyal ve Metot}

\subsection{Biyokütlenin üretimi}

Krom $\left(\mathrm{Cr}^{+3}\right)^{\prime}$ un toksik etkisini araştırmak üzere maya $(S$. cerevisiae) kullanılmıştır. S. cerevisiae mikroorganizması Pakmaya A.Ş.' den temin edilmiştir. S. cerevisiae cinsi mayaların geliştirilmesinde Malt Extract Broth (Malt extract $17.0 \mathrm{~g} / \mathrm{L}+$ Mycological peptone $3.0 \mathrm{~g} / \mathrm{L}, \mathrm{pH}: 5.4 \pm 0.2$ ) sivı besiyeri, mayaların ekim ve sayım işlemi için Malt Extract Agar (Malt extract $30.0 \mathrm{~g} / \mathrm{L}+$ Mycological peptone $5.0 \mathrm{~g} / \mathrm{L}+$ Agar No. $215.0 \mathrm{~g} / \mathrm{L}$, pH: $5.4 \pm 0.2)$ kullanılmıştır. Besiyeri bileşimindeki maddeler distile su ile çözündükten sonra otoklavda $121^{\circ} \mathrm{C}^{\prime}$ de 15 $\mathrm{dk}$ süreyle steril edilmiş̧ir. Çalışma süresince $S$. cerevisiae mikroorganizmasını içeren kuru maya örneği $+4^{\circ} \mathrm{C}^{\prime} \mathrm{de}$ saklanmıştır. Bütün kültürler $30^{\circ} \mathrm{C}$ ' de çalkalamalı etüvde (Gerhardt-Laboshake) 150 rpm' de inkübe edilmiştir [11]. Maya örneğinden $200 \mathrm{mg}$ tartılarak $10 \mathrm{~mL}$ Malt Extract Broth (MEB) içeren tüpe ekim yapılmıştır. $30^{\circ} \mathrm{C}^{\prime}$ de 24 saat bekletilerek ön zenginleștirme ișlemi yapılmıștır. Zenginleștirilmiş maya örneğinden $1 \mathrm{~mL}$ alınarak 100 $\mathrm{mL}$ MEB içeren erlene aşıllama yapılarak etüvde $30^{\circ} \mathrm{C}^{\prime}$ de 12 saat inkübasyona bırakılmıştır [12].

\section{2. Çalışma prosedürlerinin belirlenmesi}

\subsubsection{Deneyde kullanılan çözeltilerin hazırlanması}

- $\mathrm{Cr}^{+3}$ çözeltisinin hazırlanmasl: $200 \mu \mathrm{g} / \mathrm{mL}$ stok $\mathrm{Cr}^{+3}$ çözeltisi $\mathrm{CrCl}_{3} .6 \mathrm{H}_{2} \mathrm{O}$ (Merck) tuzundan hazırlanmıştır.

- C vitamini çözeltisinin hazırlanmast: $200 \mu \mathrm{g} / \mathrm{mL}$ stok C vitamini çözeltisi C vitamini standardından (Merck) hazırlanmıştır.

- Lizozom enziminin hazırlanışl: 46400 Unite/mg Lizozom enzim standartından (Sigma) 20 mg tartılmış pH' 17.38 olarak hazırlanan fosfat tamponundan $1.5 \mathrm{~mL}$ eklenilerek enzimin iyice çözünmesi sağlanmıştır. Maya mikroorganizmasının parçalanmasında bu enzim kullanılmıştır.

\subsubsection{Metal-mikroorganizma etkileşiminde uygun pH' in belirlenmesi}

Metal-mikroorganizma (biyosorpsiyon) prosesinde $\mathrm{pH}$ en önemli faktördür. Yapılan literatür çalışmalarında pH değeri düşük çözeltilerde ortamda bulunan fazla miktardaki protonlar ile metal iyonları yarışmaktadır. Böylece hücre-metal etkileşimi de azaltmaktadır. Ancak ortamın $\mathrm{pH}$ değeri arttıkça metal iyonları daha fazla bağlanmaktadır. Ortamın $\mathrm{pH}$ değeri giderek artarsa ortamdaki $\mathrm{OH}^{-}$iyon konsantrasyonu da artacağından metal iyonları çökmektedir [12]. Literatürde $S$. cerevisiae mayasının optimum çoğalma pH değerinin 3 ile 7 arasında olduğu belirlenmiştir [13]. Çalışmamızdaki uygun $\mathrm{pH}$ değerini belirlemek için; beş erlene maya kültürümüzden aynı miktarda alınmıştır. Kültür örneklerine stok $10 \mu \mathrm{g} / \mathrm{mL} \mathrm{Cr}^{+3}$ çözeltisinden aynı miktarlarda eklenmiştir. Örneklerin pH' $13,4,5,6,7$ olacak şekilde $1 \mathrm{M} \mathrm{HCl}$ ve $1 \mathrm{M} \mathrm{NaOH}$ çözeltileri ile ayarlanmıştır. $30^{\circ} \mathrm{C}^{\prime}$ deki çalkalamalı etüve bırakılarak maya kültürlerinin 12, 24 ve 36. saatlerindeki hücre sayıları (cfu/mL) araştırılmıştır.

\subsubsection{Metal-mikroorganizma etkileşiminde uygun $\mathrm{Cr}^{+3}$ dozlarının belirlenmesi (LD50)}

Maya (S. cerevisiae)' da kromun toksik etkisini araştırmak için; aynı miktar maya örneklerine 10, 20, 30, 40 ve $50 \mu \mathrm{g} / \mathrm{mL}$ stok $\mathrm{Cr}^{+3}$ çözeltilerinden aynı miktarda eklenmiştir. Bütün örnekler $\mathrm{pH}=4^{\prime}$ 'e ayarlanarak $30^{\circ} \mathrm{C}^{\prime}$ deki çalkalamalı etüve bırakılmıştır. Başlangıç kültür numunesi ile değişik konsantrasyonlarda $\mathrm{Cr}^{+3}$ eklenen numunelerin 12,24 ve 36 . Saatteki hücre sayıları (cfu/mL)' nın nasıl değiştiği belirlenmiştir.

\subsubsection{Metal-mikroorganizma etkileşiminde uygulanacak $C$ vitamini dozlarının belirlenmesi}

$200 \mu \mathrm{g} / \mathrm{mL}$ C vitamini stok çözeltisi C vitamini standartından hazırlanmıştır. Çalışmamızda 10 ve $40 \mu \mathrm{g} / \mathrm{mL}$ krom $\left(\mathrm{Cr}^{+3}\right)$ dozuna maruz bırakılan maya örneklerimizin bazılarına 10,15 ve $20 \mu \mathrm{g} / \mathrm{mL}$ konsantrasyonlarda $\mathrm{C}$ vitamini çözeltileri eklenmiş̧ir. Kromun toksik etkilerine karşı farklı konsantrasyonlarda eklenen C vitamininin biyokimyasal paramatreler üzerine etkileri araştırılmışır. 


\subsubsection{Deney düzeneğinin hazırlanması}

Saf olarak üretilen maya örnekleri dokuz gruba ayrıldı:

$\underline{\text { Grup } 1}=$ maya örneği + su

$\underline{\text { Grup 2 }}=$ maya örneği $+10 \mu \mathrm{g} / \mathrm{mL}$ krom III klorür tuzu $+\mathrm{su}$,

$\underline{\text { Grup 3 }}=$ maya örneği $+10 \mu \mathrm{g} / \mathrm{mL}$ krom III klorür tuzu $+10 \mu \mathrm{g} / \mathrm{mL}$ C vitamini+su,

$\underline{\text { Grup 4 }}=$ maya örneği $+10 \mu \mathrm{g} / \mathrm{mL}$ krom III klorür tuzu $+15 \mu \mathrm{g} / \mathrm{mL}$ C vitamini+su,

$\underline{\text { Grup 5 }}=$ maya örneği $+10 \mu \mathrm{g} / \mathrm{mL}$ krom III klorür tuzu $+20 \mu \mathrm{g} / \mathrm{mL}$ C vitamini $+\mathrm{su}$,

$\underline{\underline{\text { Grup } 6}}=$ maya örneği $+40 \mu \mathrm{g} / \mathrm{mL}$ krom III klorür tuzu $+\mathrm{su}$,

$\underline{\underline{\text { Grup } 7}}=$ maya örneği $+40 \mu \mathrm{g} / \mathrm{mL}$ krom III klorür tuzu $+10 \mu \mathrm{g} / \mathrm{mL}$ C vitamini $+\mathrm{su}$,

$\underline{\text { Grup } 8}=$ maya örneği $+40 \mu \mathrm{g} / \mathrm{mL}$ krom III klorür tuzu $+15 \mu \mathrm{g} / \mathrm{mL}$ C vitamini+su,

$\underline{\text { Grup 9 }}=$ maya örneği $+40 \mu \mathrm{g} / \mathrm{mL}$ krom III klorür tuzu $+20 \mu \mathrm{g} / \mathrm{mL}$ C vitamini $+\mathrm{su}$,

katılarak $120 \mathrm{~mL}$ örnekler hazırlanmıştır. Toplam $120 \mathrm{~mL}$ örnek hazırlamak için; $10 \mu \mathrm{g} / \mathrm{mL} \mathrm{Cr}^{+3}$ uygulanacak gruplara $(6 \mathrm{~mL}), 40 \mu \mathrm{g} / \mathrm{mL} \mathrm{Cr}^{+3}$ uygulanacak gruplara $(24 \mathrm{~mL})$ stok $\mathrm{Cr}^{+3}$ çözeltisinden eklenmiştir. Ayrıca 10 $\mu \mathrm{g} / \mathrm{mL} \mathrm{C}$ vitamini uygulanacak gruplara $(6 \mathrm{~mL}), 15 \mu \mathrm{g} / \mathrm{mL} \mathrm{C}$ vitamini için $(9 \mathrm{~mL}), 20 \mu \mathrm{g} / \mathrm{mL} \mathrm{C}$ vitamini için $(12$ $\mathrm{mL}$ ) stok $\mathrm{C}$ vitamini çözeltisinden ilave edilmiştir. Bütün numuneler $\mathrm{pH}=4$ ' e ayarlanmıştır.

\subsubsection{Ham özüt hazırlanması}

Sıvı besi ortamındaki hücrelerden ham özüt hazırlanmıştır [14]. Kontrol grubu ve $\mathrm{Cr}^{+3}$ uygulanmış deney grubundaki hücreler, 4500 rpm' de 20 dakika santrifüj edilerek çöktürülmüştür. Hücre çökeltisi $2.0 \mathrm{~mL}$ steril saf su ile 2 kez yıkanılarak pH' 17.38 olan fosfat tamponu ile sulandırılmış lizozom enziminden hücre çökeltisine 2 damla eklenip $5 \mathrm{dk}$ vortekslenmiştir. Örnekler $1.5 \mathrm{~mL}$ deiyonize su ile süspanse edilmiştir. Her bir örnek üzerine asit ile yıkanmış $1.0 \mathrm{~g}$ cam boncuk $(0.25-0.30 \mathrm{~mm}$ çapında) eklendikten sonra tekrar vortekslenerek ultrasonik su banyosunda $15 \mathrm{dk}$ bekletilmiştir. Örnekler $10 \mathrm{dk}$ santrifüjlenerek üst sıvıdan $1 \mathrm{~mL}$ alınarak numune tüplerine aktarılmıştır. Elde edilen ham özütler deneylerde kullanılmak üzere $-20^{\circ} \mathrm{C}$ ' da saklanılmıştır.

\subsubsection{Maya örneklerinin A ve E vitamini miktarlarının belirlenmesi}

Maya özütlerinden $1 \mathrm{~mL}$ alınarak $2 \mathrm{~mL}$ etanol: sülfürik asit (99:1) karışımından ilave edilmiştir. Bu şekilde proteinlerin çöktürülmesi sağlanmıştır. Numuneler vorteks ile iyice karıştırıldıktan sonra 4500 devirde santrifüjlenmiş̧tir. Santrifüjlenen numunelere $0.5 \mathrm{~mL}$ n-hekzan ilave edilerek tekrar santrifüjlenmişstir. Santrifüj sonunda hekzan fazı dikkatli bir şekilde ayrılarak cam tüpe alınmıştır. Bu işlem iki defa tekrarlanılarak hekzan fazları birleştirilmiştir. Ekstrakte edilen hekzan fazı azot gazı ile dikkatlice ortamdan uzaklaştırılarak tüpteki kalıntı $0.1 \mathrm{~mL}$ metanolde çözülmüştür. Bu çözeltiden $20 \mu \mathrm{L}$ alınarak yüksek performanslı sıvı kromatografisi cihazına verilmiştir. Bu cihazda mobil faz metanol: su (98:2) çözeltisi ve SUPELCOSIL LC-18 kolonu kullanılarak 326 nm'de A vitamini ve 296 nm'de E vitamini belirlenmiştir $[15,16]$.

\subsubsection{Maya örneklerinin C ve MDA miktarlarının belirlenmesi}

Maya özüt örneklerinden $1 \mathrm{~mL}$ alınarak $0.5 \mathrm{M} \mathrm{HClO}_{4}$ çözeltisinden $0.5 \mathrm{~mL}$ eklenip vortekslenmiştir. Vortekslenen bu karışımın 4500 rpm' de 5 dk santrifüjlenerek içerisindeki proteinlerin çöktürülmesi sağlanmıştır. Santrifüjlenen örneğin üzerindeki berrak kısımdan $20 \mu \mathrm{L}$ alınıp HPLC cihazına verilmiştir. $245 \mathrm{~nm}$ dalga boyu, (3.7 mM KH $2 \mathrm{PO}_{4} \mathrm{pH}=4$ ) hazırlanan mobil faz ve Inertsil ODS-4 kolonu kullanılarak örneklerdeki $\mathrm{C}$ vitamini miktarları belirlenmiştir [17]. Örneklerdeki MDA miktarları; C vitamini tayini için hazırlanmış olan süzüntüden yine $20 \mu \mathrm{L}$ alınarak HPLC cihazına verilmiştir. Inertsil ODS-4 kolonu ve pH: 4'e fosforik asit ile ayarlanmış 30 mM KH${ }_{2} \mathrm{PO}_{4}-\mathrm{CH}_{3} \mathrm{OH}(\% 65-\% 35)$ karışımını içeren mobil faz kullanılarak $254 \mathrm{~nm}$ dalgaboyunda örneklerin MDA miktarı belirlenmiştir [18].

\subsubsection{Maya örneklerinin glutatyon (GSH, GSSG) miktarlarının belirlenmesi}


GSH ve GSSG miktarlarının belirlenmesi için maya süpernatant örneklerinden $1 \mathrm{~mL}$ alınmıştır. $0.5 \mathrm{M} \mathrm{HClO}_{4}$ çözeltisinden $0.5 \mathrm{~mL}$ ilave edilerek vortekslenmiştir. Karışım $4500 \mathrm{rpm}$ ' de 5 dk santrifüjlenerek proteinlerin çöktürülmesi sağlanmıştır. Santrifüjlenen numuneden $20 \mu \mathrm{L}$ alınarak HPLC cihazına verilmiştir. Analizlerde EXSIL 100-5ODS kolonu ve \% $0.1 \mathrm{H}_{3} \mathrm{PO}_{4}$ kullanılarak hazırlanmış olan $50 \mathrm{mM} \mathrm{NaClO} 4$ mobil faz çözeltisi kullanılarak 215 nm’ de örneklerdeki glutatyon (GSH ve GSSG) miktarları tayin edilmiştir [19].

\subsubsection{0. İstatistiksel değerlendirme}

Bu çalışmada incelenen her bir grup için tekrar sayısı $(n)=3$ olacak şekilde analiz edilmiştir. Çalışmadaki sonuçlar ortalama \pm standart sapma olarak verilmiştir. Deneysel sonuçlar SPSS 17.0 istatistiksel bilgisayar programı ile hesaplanmış, sonuçların değerlendirilmesinde One-Sample T testi kullanılmıştır. Anlamlılık düzeyi $\mathrm{p}<0.05$ olarak belirlenmiştir.

\section{Sonuçlar}

Başta başlangıç kültürü olmak üzere 3-7 arasında değişik pH' larda maya (S. cerevisiae)' nın 12, 24. ve 36. saatteki hücre sayıları (cfu/mL) belirlenmiştir. Maya (S. cerevisiae) ile krom (III) toksik etkileşimin pH 5 ve sonrasında olmadığı, pH 3' de ise etkileşimin fazla derecede olduğu belirlenmiştir. Bu çalışmada bazı biyokimyasal parametre miktarlarının ölçülebilmesi için; krom metali ile maya mikroorganizmasının pH 4' teki toksik etkileşiminin incelenmesine karar verilmiştir. Sonuçlar Şekil 1' de gösterilmiştir.

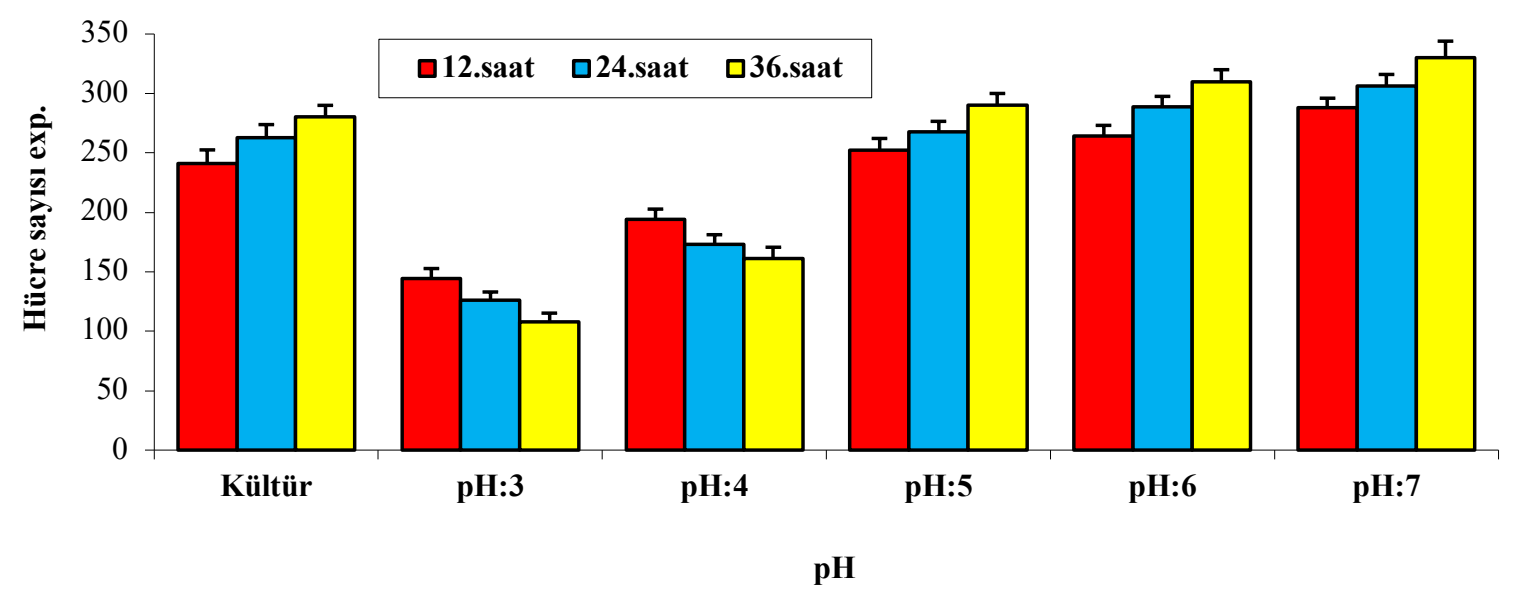

Şekil 1. S. cerevisiae ile krom etkileşiminde uygun pH' ın belirlenmesi (Grafikteki hücre sayıları 106 ile çarpılmalıdır).

Metal-mikroorganizma etkileşiminde diğer bir faktör de uygun (LD50) krom (III) dozlarının belirlenmesidir. $\mathrm{Bu}$ amaçla 10-50 $\mu \mathrm{g} / \mathrm{mL}$ konsantrasyonlardaki krom (III) metali çözeltileri ile maya mikroorganizmasının pH 4' teki toksik etkileşimi incelenmiştir. Sonuçlar Şekil 2' de gösterilmiştir. $50 \mu \mathrm{g} / \mathrm{mL}$ konsantrasyondaki kromun lethal doz olduğu gözlemlenmiştir. Bu sebeple çalışmada 10 ve $40 \mu \mathrm{g} / \mathrm{mL}$ olmak üzere iki farklı krom (III) dozlarının kullanılmasına karar verilmiştir. 


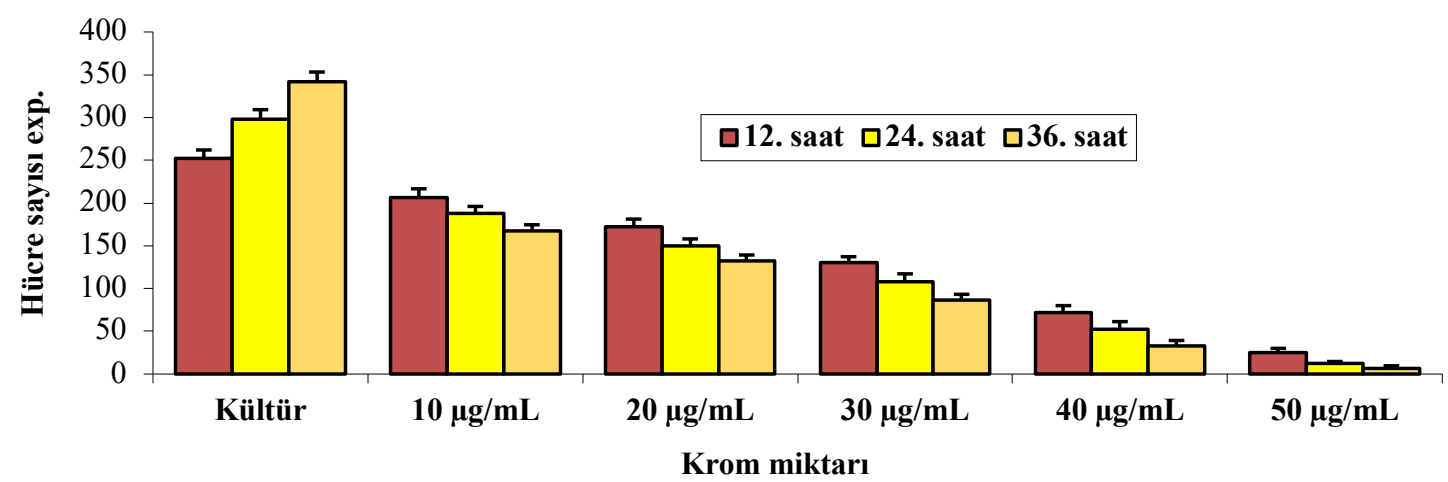

Şekil 2. S. cerevisiae’ ya uygulanacak uygun krom dozlarının belirlenmesi (Grafikteki hücre sayıları $10^{6}$ ile çarpılmalıdır)

Maya mikroorganizmasına uygulanmak üzere 10 ve $40 \mu \mathrm{g} / \mathrm{mL}$ derişimlerde olmak üzere iki farkl $\mathrm{Cr}^{+3} \mathrm{dozu}$ seçilmiştir. Krom ile muamele edilen maya örneklerine $C$ vitamininin etkisini araştırmak için 10, 15 ve $20 \mu \mathrm{g} / \mathrm{mL}$ olmak üzere üç farklı konsantrasyonda $\mathrm{C}$ vitamini çözeltilerinden ilave edilmiştir. Deney gruplarındaki mayaların hücre sayıları ile antioksidan vitaminleri (A, E, C), malondialdehit ve glutatyon miktarları (Şekil 3-11)’ de gösterilmiştir.

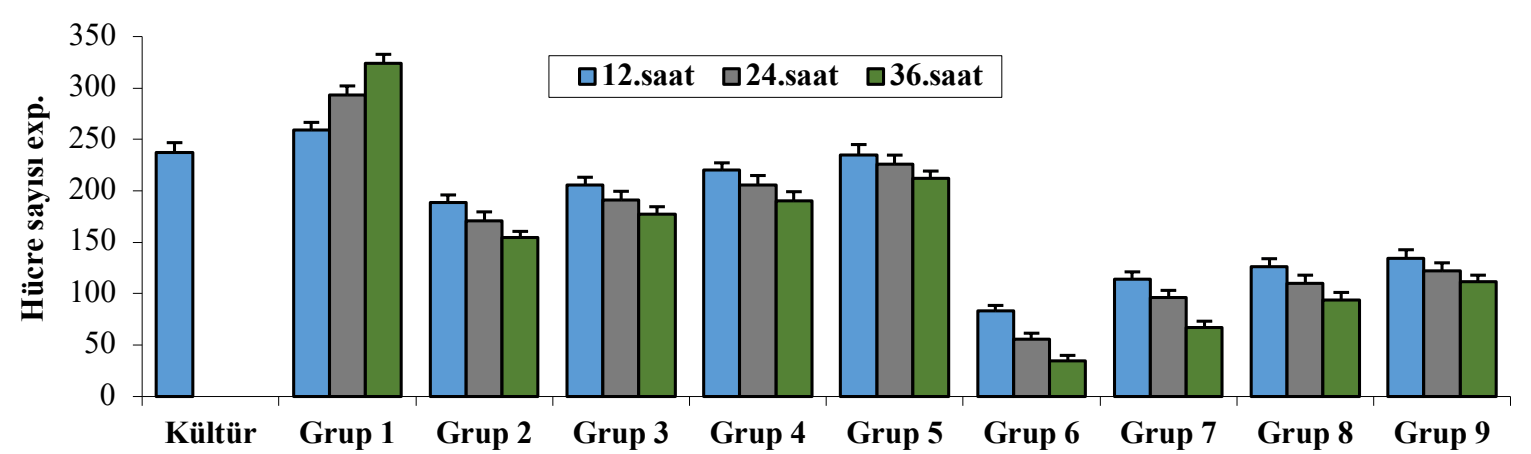

Şekil 3. Antioksidan vitaminler, malondialdehit ve glutatyon miktarlarının incelendiği kültürlerdeki hücre sayıları (cfu/mL) (Grafikteki hücre sayıları $10^{6}$ ile çarpılmalıdır).

Zamana bağlı olarak S. cerevisiae maya örneklerinin A vitamini miktarlarındaki değişim Şekil 4' de gösterilmiştir.

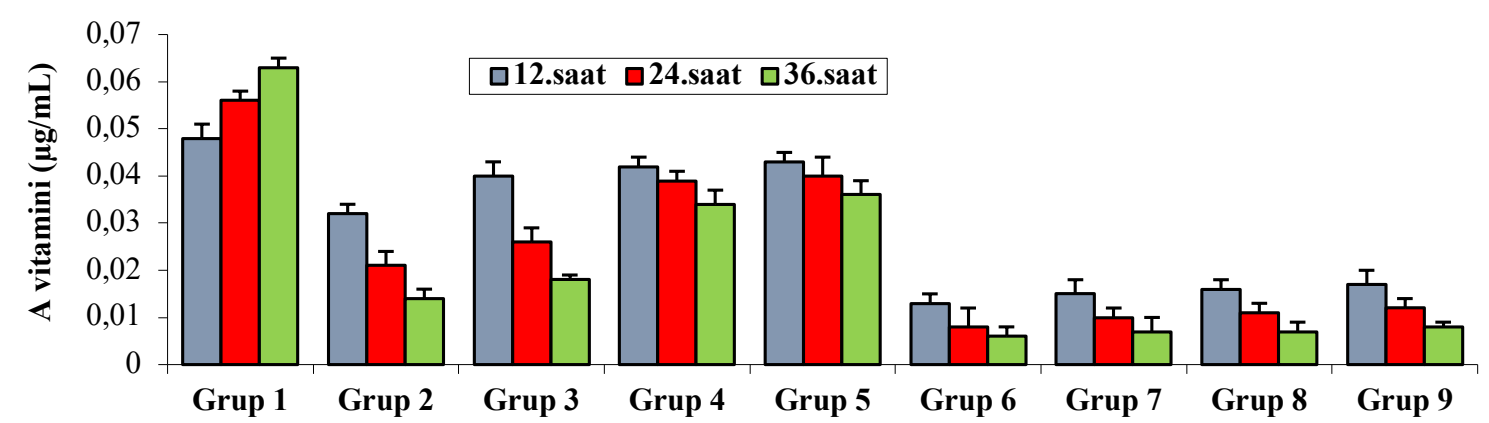

Şekil 4. Deney gruplarında süreye bağlı olarak A vitamini miktarlarındaki değişim grafiği

S. cerevisiae mikroorganizma örneklerinin zamana bağlı olarak E vitamini miktarlarındaki değişim Şekil 5' de gösterilmiştir. 


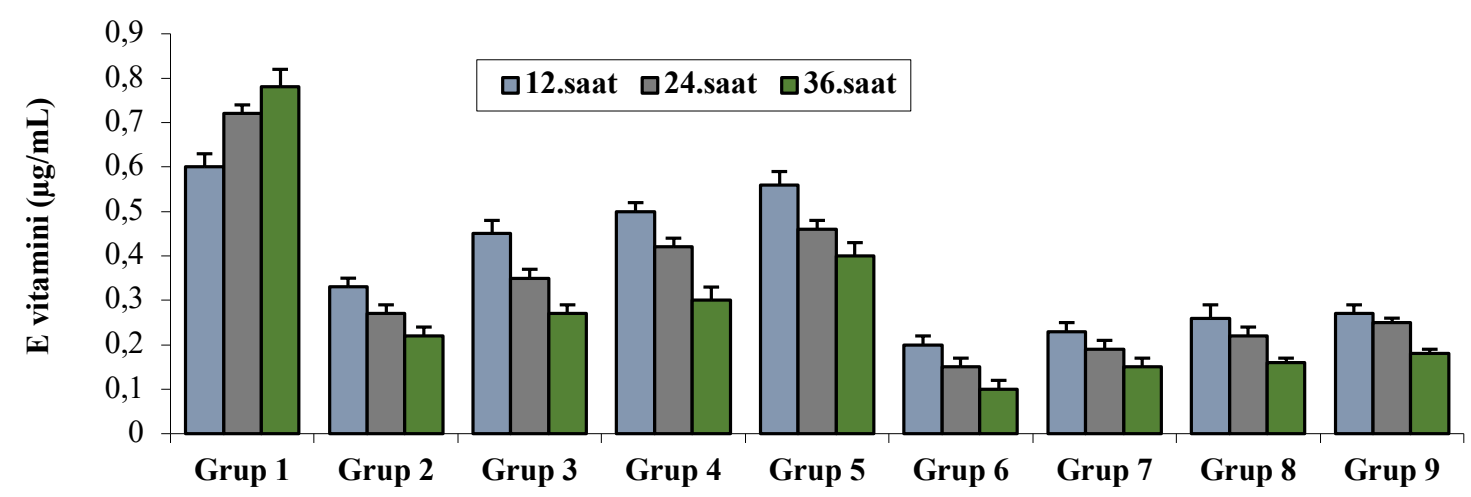

Şekil 5. Deney gruplarında süreye bağlı olarak E vitamini miktarlarındaki değişim grafiği

Zamana bağlı olarak S. cerevisiae maya örneklerinin C vitamini miktarlarındaki değişimler Şekil 6' da gösterilmiştir.

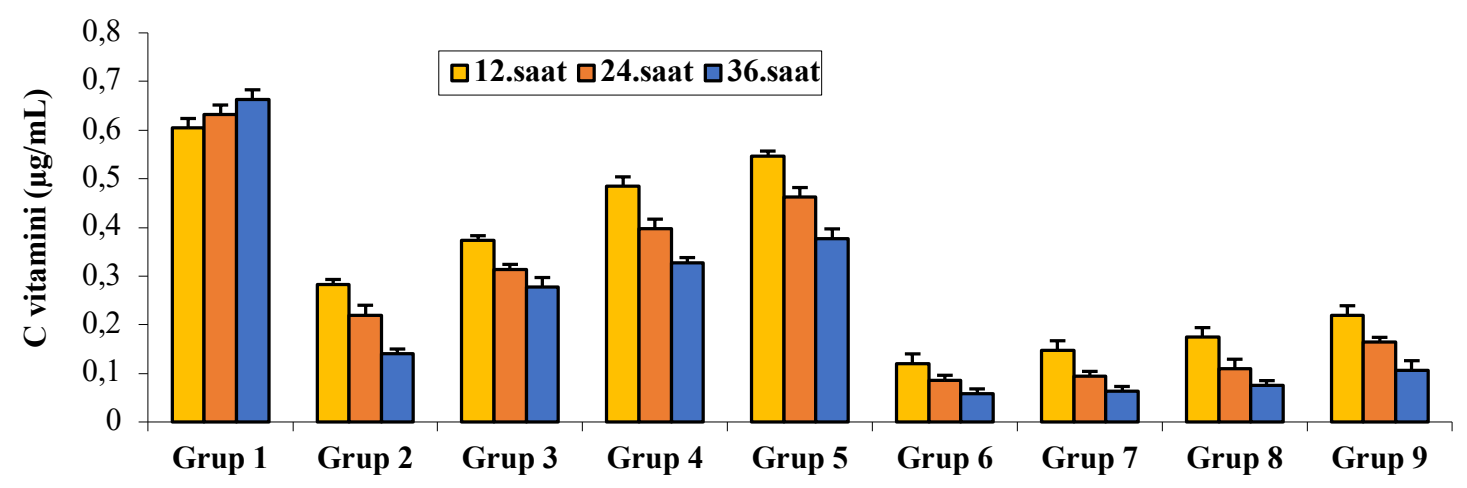

Şekil 6. Deney gruplarında süreye bağlı olarak C vitamini miktarlarındaki değişim grafiği

Zamana bağlı olarak S. cerevisiae deney gruplarının malondialdehit (MDA) miktarlarındaki değişim Şekil 7' de gösterilmiştir.

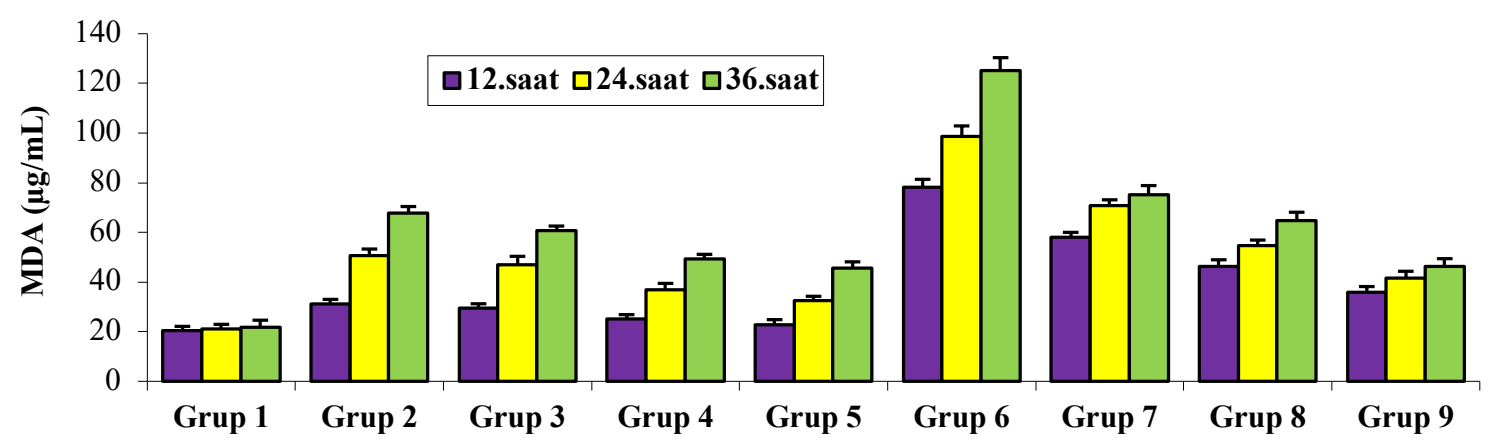

Şekil 7. Deney gruplarında süreye bağlı olarak MDA miktarlarındaki değişim grafiği

Zamana bağlı olarak maya örneklerindeki GSH ve GSSG miktarları (Şekil 8-10) ile GSH/GSSG oranları üzerine etkileri (Şekil 11)’ de gösterilmiştir. 


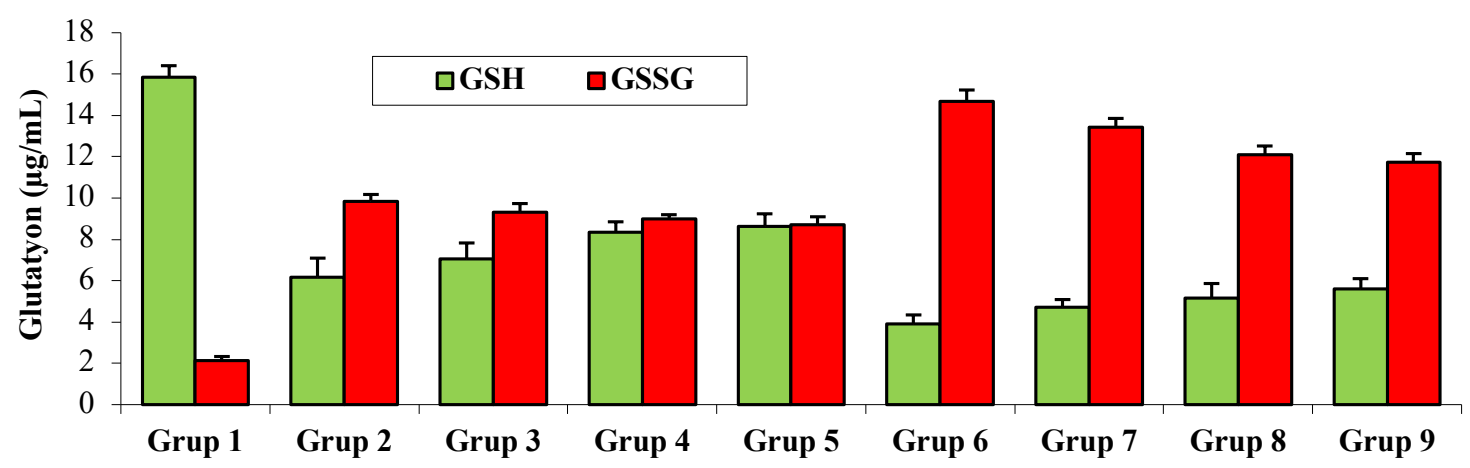

Şekil 8. Maya örneklerinin 12. saatteki GSH ve GSSG değerleri

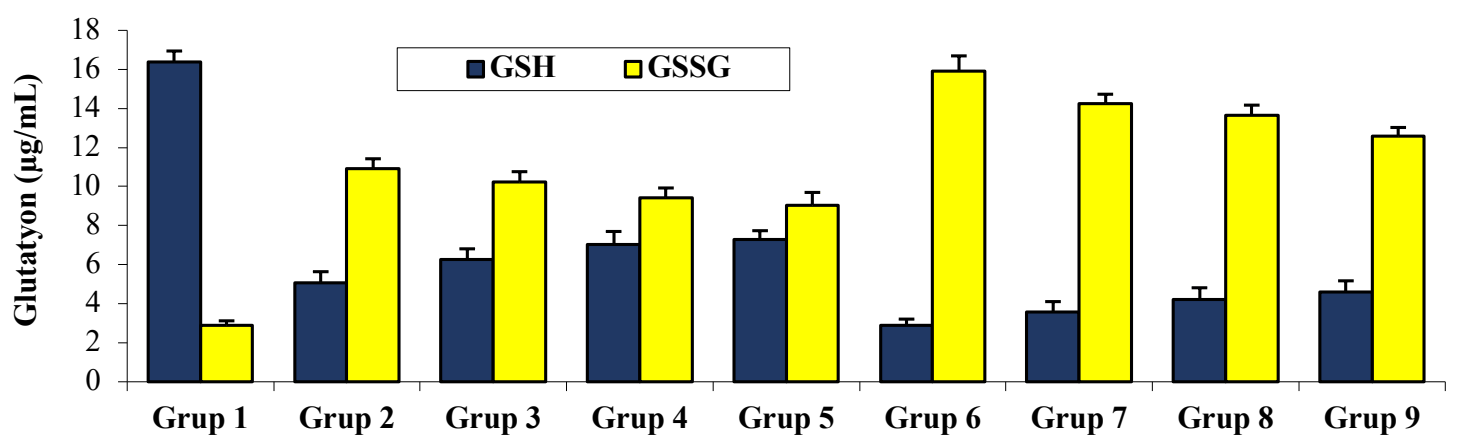

Şekil 9. Maya örneklerinin 24. saatteki GSH ve GSSG değerleri

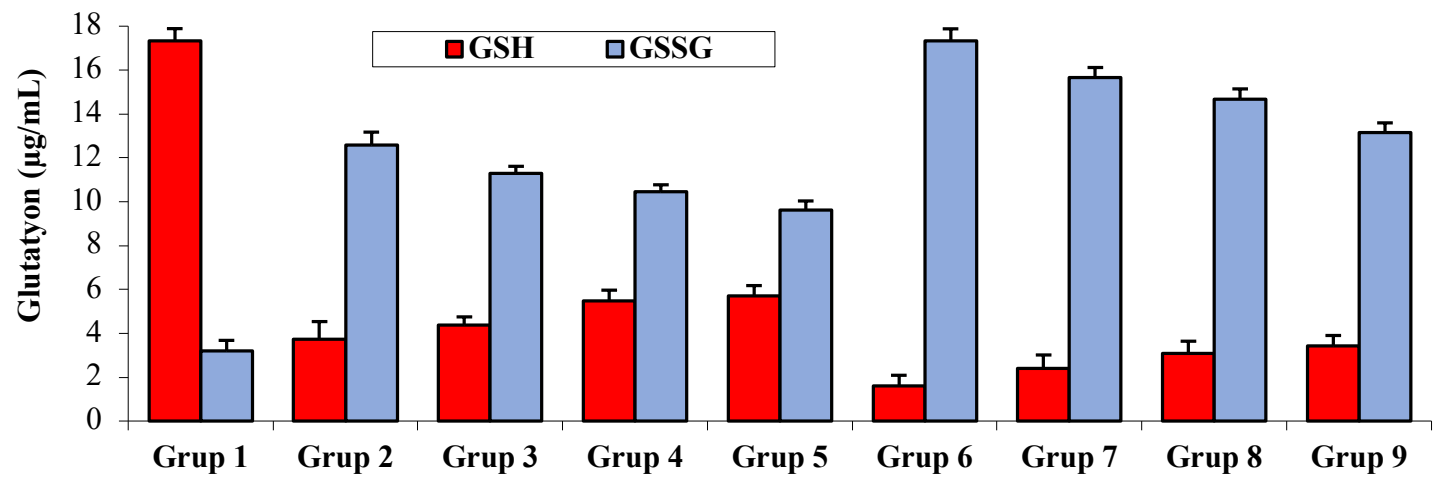

Şekil 10. Maya örneklerinin 36. saatteki GSH ve GSSG değerleri

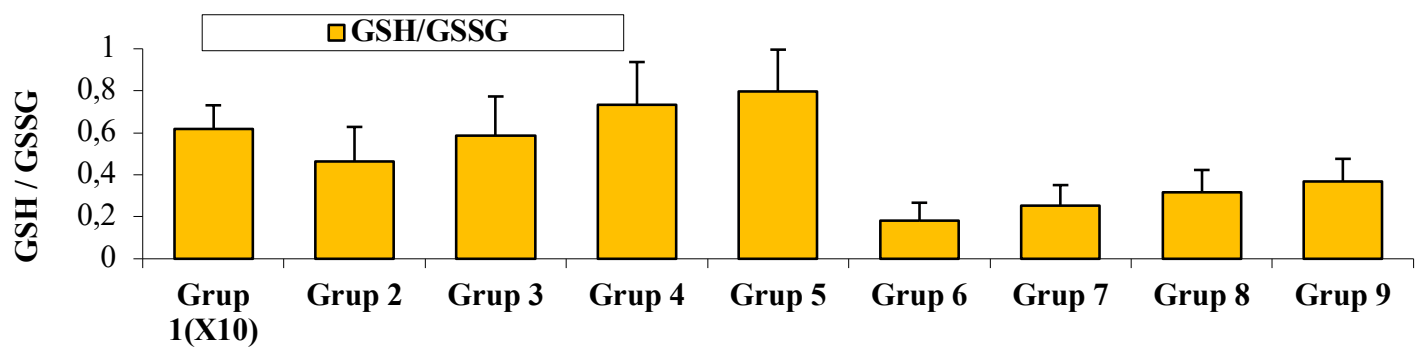

Şekil 11. Maya örneklerinin 12, 24 ve 36. saatteki GSH/GSSG oranlarının ortalama değerleri 


\section{Tartışma}

Krom protein, yağ ve karbonhidrat metabolizması için gerekli mikro besindir. Ancak fazla miktarlarının toksik etki yaptığı bildirilmiştir [20]. Kromdan etkilenen diğer bir canlı grubu maya mikroorganizmasıdır. Toksik metallere karşı mayalar ya metallerin alınımının ve geçişinin azaltılması veya hücrelerinin metalleri tutması yoluyla direnç gösterebilmektedirler [21]. Bütün çalışmalarımız maya mikroorganizmasının üstel fazındaki üremesi esnasında alınan kültürlerle yapılmıştır. Canlı hücre sayısının maksimum seviyede olduğu bu evrede, krom-maya etkileşiminin araştırılması amaçlanmıştır.

$\mathrm{Bu}$ çalışmada, dokuz farklı gruba ayrılmış maya örneklerinin 12, 24 ve 36. saatteki hücre sayıları incelenmiştir. Kontrol grubu ile iki farklı krom dozunun uygulandığı maya örneklerinin hücre sayıları karşılaştırıldığında, krom dozlarının uygulandığı örneklerin hücre sayılarında azalmalar $(\mathrm{p}<0.005)$ tespit edilmiştir. Fakat ortama farklı dozlarda C vitamini eklenmesiyle doza bağlı olarak hücre sayılarının da arttığı $(\mathrm{p}<0.005)$ belirlenmiştir. Ayrıca kontrol grubunda zamana bağlı olarak maya hücre sayılarında artışlar $(\mathrm{p}<0.005)$ gözlenmiş iken, diğer gruplarda zamana bağlı olarak düşüş̧lerin ( $\mathrm{p}<0.05$ ) olduğu tespit edilmiştir (Şekil 3 ). $\mathrm{H}_{2} \mathrm{O}_{2}$ ile stres oluşturulmuş Schızosaccharomyces Pombe mayasında yapılan bir araştırmada S. pombe hücrelerinde canlılık oranlarının, $\mathrm{H}_{2} \mathrm{O}_{2}$ derişimi ile ters orantılı olarak değiştiği rapor edilmiştir [22].

Metabolizmada ortaya çıkan radikallerin önlemesi ve aktif oksijen türlerinin durdurulmasında karotenoidlerin önemli görevleri vardır [23]. Bu çalışmada, kontrol grubu maya örneklerinin zamana bağlı olarak A vitamini miktarlarında artmalar ( $\mathrm{p}>0.05)$ gözlenirken, kromun artan dozuna karşıllık maya örneklerinin A vitamini miktarlarında azalmalar $(\mathrm{p}<0.05)$ olduğu belirlenmiştir. Ortama katılan $\mathrm{C}$ vitamini doz artışına paralel olarak da maya örneklerinin A vitamini miktarlarında artışların ( $<<0.05$ ) olduğu tespit edilmiştir (Şekil 4). S. cerevisiae ve bazı ağır metallerin biyosorpsiyonu ile ilgili yapılan bir çalışmada, ağır metal uygulamalarının maya hücresi A vitamini miktarlarında düşüşlere yol açtı̆̆ bildirilmiş̧ir [24].

E vitamininin antioksidan kapasitesi oldukça geniş ve yüksektir. Bu antioksidan kapasitesini zararlı radikallerin yok edilmesi, etkisinin azaltılması ve bozduğu yapıların tamiri gibi çeşitli mekanizmaları kullanarak yerine getirmektedir $[25,26]$. Bu çalışmada kontrol grubu maya örneklerinin zamana bağlı olarak E vitamini miktarlarında artmaların $(\mathrm{p}<0.05)$ olduğu, kromun artan dozuna bağlı olarak maya örneklerinin $\mathrm{E}$ vitamini miktarlarında azalmalar $(\mathrm{p}<0.05)$ olduğu gözlenmiştir. Ortama katılan $\mathrm{C}$ vitamini doz artışına paralel olarak maya örneklerinin E vitamini miktarlarında artışların $(\mathrm{p}<0.05)$ olduğu belirlenmiştir (Şekil 5). $\mathrm{H}_{2} \mathrm{O}_{2}$ ile stres oluşturulmuş mikroorganizma $S$. cerevisiae'da, $\alpha$-tokoferol'ün koruyucu etkileri araştırılmış ve stres oluşturulan grupların hücre sayısının kontrol grubuna göre düşük olduğu görülmüştür. Ayrıca $\alpha$-tokoferol ilave edilen grupların hücre sayısının, stres oluşturulan grupların hücre sayısından fazla olduğu bildirilmiştir [27]. Bulgularımızın birbirleriyle ve literatürlerle uyumlu oldukları görülmektedir.

C vitamininin antioksidan olarak görevi, lipit hidroperoksitlerin oluşumunu önlemektir. Özellikle bu vitamin peroksit ve süperoksit gibi reaktif oksijen türlerinin indirgenmesinde görev almaktadır [28]. Yapılan bir çalışmada, $\mathrm{CrO}_{3}$ verilen farelerin dokularındaki askorbik asit miktarlarının kontrol grubuna göre düşük olduğu bildirilmiştir [29]. Bu çalışmada kontrol grubu $\mathrm{C}$ vitamini miktarlarında artışlar $(\mathrm{p}<0.005)$ gözlenirken, diğer tüm gruplarda zamana bağlı olarak $\mathrm{C}$ vitamini miktarlarında düşüşler $(\mathrm{p}<0.05)$ tespit edilmiştir. Ayrıca kromun artan dozlarına bağlı olarak örneklerdeki $C$ vitamini miktarlarında azalma $(\mathrm{p}>0.05)$ gözlenmiş iken, ortama ilave edilen $\mathrm{C}$ vitamini dozuna paralel olarak da örneklerdeki $C$ vitamini miktarlarında artışların $(\mathrm{p}<0.05)$ olduğu belirlenmiştir (Şekil 6). Ayrıca ortama C vitamini katılması ve S. cerevisiae' ların C vitamini sentezleme yeteneklerden dolayı [30], mayalardaki $\mathrm{C}$ vitamini miktarlarındaki artışın olması beklenen bir sonuçtur. Artan krom dozuna karşılık $\mathrm{C}$ vitamini miktarındaki düşüşün sebebi ise, kromun oluşturduğu serbest radikallerin temizlenmesi ve zararsız hale getirilmesinde kullanılmış olabileceği sonucunu akla getirmiştir.

Kromun en önemli özelliklerinden biri değerlik değiştirip yok olmamasıdır. Bu yüzden kromun serbest radikal uyarımı ile ilişkili olduğuna inanılmaktadır [31,32]. Metabolizmada stres sonucu oluşan bu zararlı radikaller, hücre zarının yapısında bulunan doymamış yağ asitlerine etki etmektedirler. Bu olay sonucu lipid peroksidasyon meydana gelmektedir. Lipid peroksidasyonu sonucunda malondialdehit (MDA) adı verilen reaktif karbon bileşikleri oluşmaktadır [33]. Metabolizmadaki serbest radikal oluşumunu arttıran maddelerin, MDA düzeyini arttırdığı ancak vitamin seviyelerini azalttığı bildirilmiştir [34]. Bu çalışmada, kontrol grubu maya örneklerinin zamana bağlı olarak MDA miktarında artışlar $(\mathrm{p}<0.005)$ gözlenirken, diğer tüm gruplarda da zamana bağlı olarak MDA miktarlarında artışlar $(p<0.05)$ tespit edilmiştir (Şekil 7). Kontrol grubu maya örneğinde zamana bağlı olarak MDA miktarında artışın olması, maya hücrelerinin çoğalması sırasındaki stresten kaynaklanmış olabileceğini göstermektedir. Kromun artan dozuna bağlı olarak MDA miktarlarında artışlar gözlenirken $(\mathrm{p}<0.05)$, ortama ilave edilen $\mathrm{C}$ vitamini dozuna paralel olarak da MDA miktarlarında düşüşlerin $(p<0.05)$ olduğu belirlenmiştir. Kromun maya mikroorganizmasında oksidatif stres oluşturarak, serbest radikallerin artışına sebep 
olduğu tespit edilmiştir. Dolayısıyla maya örneklerinin de MDA miktarlarında artışlara yol açmıștır. Ancak kültür ortamına ilave edilen $\mathrm{C}$ vitamininin antioksidan vitamin olması münasebetiyle, serbest radikal oluşumunu önlediği belirlenmiştir. Bazı ağır metaller $(\mathrm{Mn}, \mathrm{Mg}, \mathrm{Cd}, \mathrm{Fe})$ ve $S$. cerevisiae ile yapılan bir çalışmada; ağır metal uygulamalarının maya hücresinde MDA miktarlarında artışlara, vitamin miktarlarında da düşüşlere yol açtığı bildirilmiştir [24]. Sonuçlarımızın literatürlerle uyumlu olduğu görülmüştür.

Glutatyon (GSH) glutamik asit, sistein ve glisin gibi aminoasitlerden oluşan bir tripeptit' tir. Glutatyon hücreyi özellikle oksidatif stres olmak üzere tüm çevresel stres koşullarına karşı korumaktadır [35, 36]. Bu çalışmada 12, 24 ve 36. saatlerdeki kontrol grubu ile diğer grup maya örneklerinin GSH ve GSSG miktarları karşılaştırılmıştır. Kontrol grubuna göre diğer grupların GSH miktarlarında azalma ( $<<0.05)$, GSSG miktarlarında artma $(\mathrm{p}<0.05)$ olduğu tespit edilmiştir (Şekil 8-10). Kromun doz artışına bağlı olarak GSH miktarlarında azalma $(\mathrm{p}<0.05)$, GSSG miktarlarında ise artış $(\mathrm{p}<0.05)$ olduğu belirlenmiştir. Ortama artan dozlarda $\mathrm{C}$ vitamini ilavesi durumunda GSH miktarlarında artış ( $\mathrm{p}<0.05)$, GSSG miktarlarında ise azalma $(\mathrm{p}<0.05)$ olduğu belirlenmiştir. Her üç saatteki sonuçlar birbirini desteklemektedir. S. cerevisiae ile yapılan bir çalışmada, glutatyonun oksidatif strese karşı korumada önemli bir molekül olduğu belirtilmiş ve artan $\mathrm{H}_{2} \mathrm{O}_{2}$ derişimlerinin glutatyon (GSH) düzeyini düşürdüğü bildirilmiştir [37]. Glutatyonun redoks dengesi (GSH/GSSG) oranına bağlıdır. Metabolizmadaki oksidatif stres durumlarında bu oranın 1-10 arasında değişmektedir [38]. Glutatyon redoks dengesine (GSH/GSSG) bakıldığında, besi ortamlarına krom ilave edilen maya örneklerindeki bu oranın kontrol grubuna göre düşük olduğu görülmüştür. Krom stresine uğramış maya örneklerinde bu oran, zamana bağlı olarak azalmalar şeklinde devam etmiştir. Ayrıca GSH/GSSG oranı kontrol grubunda yüksek iken, diğer gruplarda oldukça düşük değerlerde olduğu $(\mathrm{p}<0.05)$ tespit edilmiştir. $C$ vitamini eklenen örneklerde bu oranın daha fazla olduğu ve zamana bağlı olarak azalmaların daha yavaş olduğu belirlenmiştir (Şekil 11). Krom dozunun bu oranı düşürdüğü, artan C vitamini dozunun ise bu oranı kısmen artırdığı belirlenmiştir. Maya örneklerindeki artan MDA miktarları ile maya GSH/GSSG oranındaki azalma miktarlarından kromun mayada oksidatif strese neden olduğu, oluşan bu stresi C vitaminin kısmen de olsa önlediği belirlenmiştir. Metabolizmada oksidatif strese cevapta GSH miktarlarında azalmalar, GSSG miktarlarında ise artmaların olduğu yapılan çalışmalarda bildirilmiştir [39]. Ayrıca S. cerevisiae kültür ortamına ağır metallerin ilavesi ile ilgili yapılan bir çalışmada; maya hücresinin okside glutatyon (GSSG) miktarının arttığı, redükte glutatyon miktarlarının (GSH) azaldığı ve GSH/GSSG oranının ise düştüğü belirlenmiştir [37]. Bulgularımızdaki GSH, GSSG ve GSH/GSSG oranı sonuçlarının literatürlerle uyumlu olduğu görülmektedir.

Maya hücreleri ile memeli hücreleri büyük oranda benzerdirler [40]. Maya mikroorganizması ile yapılan çalışmalarla, ökaryotik canlılardaki metabolik stres ve strese karşı verilen antioksidan cevap mekanizmaları açıklanabilmektedir. Çalışmamızda memeli hücreleri gibi ökaryotik bir canlı olan S. cerevisiae' da oksidatif strese karşı antioksidan cevap ve bu cevaba $\mathrm{C}$ vitamininin etkisi araştırılmıştır. Sonuçta kromun artan dozuna karşı A, E, C vitaminleri, GSH ve GSH/GSSG oranı miktarlarında azalmalar gözlenirken, MDA ve GSSG miktarlarında artışların olduğu belirlenmiştir. Bu sonuçlardan kromun $S$. cerevisiae' da oksidatif strese yol açtığı, ortama ilave edilen $\mathrm{C}$ vitaminin etkin bir süpürücü ve koruyucu etki gösterdiği belirlenmiştir. Uygulanan krom stresinin $S$. cerevisiae metabolizmasında değişikliğe yol açtığı gözlenmiştir. Bu tarz çalışmaların, memeli hücrelerindeki redoks dengelerinin aydınlatılması açısından faydalı olabileceği kanaatine varılmıştır.

\section{Teşekkür}

Bu çalışma Fırat Üniversitesi Bilimsel Araştırma Projesi (FÜBAP) FF 11.01 nolu proje kapsamında gerçekleştirilmiştir. Bu çalışma özgün araştırma makalesi niteliğindedir.

\section{Kaynaklar}

[1] Samson RA, Hocking AD, Pitt JI, King AD. Modern methods in food mycology. Elsevier, Amsterdam. Science Publishers pp 1992; 275-285.

[2] Phaff HJ, Mille MW, Mrak EM. The live of yeasts. Harward University Press. Cambridge p. 186, 1966.

[3] Jakobsen M, Norvhus J. Yeast and their possible beneficial and p. negative effects on the quality of dairy products. Int.Dairy Journal 1996; 6: 755-768.

[4] Hierro N, Gonzalez A, Mas A, Guillamon JM. New PCR based methods for yeast identification. Journal of Applied Microbiology 2004; 97: 792-801.

[5] Kahvecioğlu Ö, Kartal G, Güven A, Timur S. Metallerin çevresel etkileri I-II. İTÜ Metalurji ve Malzeme Mühendisliği Bölümü (Seminer çalışması 24s), 2004.

[6] Barnett JA. The taxonomy of the genus Saccharomyces Meyen ex Reess: A Short Review for Nontaxonomists. Yeast 1992; 81: 1-23. 
[7] Inoue Y, Nomura W, Takeuchi Y, Ohdate T, Tamasu S, Kitaoka A, Kiyokawa Y, Masutani H, Murata K, Wakai Y, Izawa S, Yodoi J. Efficient extraction of thioredoxin from Saccharomyces cerevisiae by ethanol. Appl Environ Microb 2007; 73: $1672-1675$.

[8] Gaspar LR, Camargo FB, Graneti MD, Mara Campos PMBG. Evaluation of dermatological effects of cosmetic formulations containing Saccharomyces cerevisiae extract and vitamins. Food and Chemical Toxicology 2008; 46-11: 3493- 3500.

[9] Piotrowska A, Mlyni K, Siwek A, Dybala M, Opoka W, Poleszak E, Nowak G. Antidepressant-like effect of chromium chloride in the mouse forced swim test: involvement of glutamatergic and serotonergic receptors. Pharmacol Rep 2008; 60 (6): 991-995.

[10] Yang L, Chen JP. Biosorption of hexavalent chromium onto raw and chemically modified Sargassum sp. Bioresource Technology In Press, 2007.

[11] Korhan H, Halipçi HN, Kertmen M, Dığrak M. Saccharomyces cerevisiae Biyokütlesi ile Remazol Navy Blue Boyar Maddesinin Biyosorpsiyonu. KSÜ Doğa Bil. Derg 2012; 15 (3).

[12] Çabuk A, Akar T, Kotluk Z, Șaşmaz S. Saccharomyces cerevisiae hücreleri ile ağır metal giderimi ve metal toleransı. Orlab On-Line Microbiyoloji Dergisi 2007; 05-3:1-7.

[13] Bailey JE, Ollis DF. Biochemical engineering Fundamentals. $2^{\text {nd }}$ Edition, Mc Graw Hill. Singapore, 1986.

[14] Jakubowsk1 W, Bartosz G. 2,7-Dichlorofluorescin oxidation and reactive oxygen species: what does it measure?. Cell Biology International 2000; 24 (10): 757-760.

[15] Miller KW, Lorr NA, Yang CS. Simultaneous determination of plazma Retinol $\alpha$-Tocopherol, Iycopene, $\alpha$-Carotene and $\beta$-Carotene by high performance liquid chromatography. Analytical Biochem 1984; 138: 340-345.

[16] Cetinkaya N, Özcan H. Investigation of seasonal variations in cow serum Retinol and $\beta$-Carotene by high performance liquid chromatographic method comp. Biochem Physiol 1991; 100 (4): 1003-1008.

[17] Cerhata D, Bauerova A, Ginter E. Determination of Ascorbic Acid in blood serum using high-performance liquid chromatography and its correlation with spectrophotometric. Caska-Slov-Farm 1994; 43 (4): 166-168.

[18] Karatas F, Karatepe M, Baysar A. Determination of free malondialdehyde in human serum by high performance liquid chromatography. Analytical Biochemistry 2002; 311: 76-79.

[19] Dawes P, Dawes E. SGE Chromatography Products Catalog (pg: 182), 2000.

[20] Mertz W. Chromium in human nutrition: a review. J Nutr 1993; 123: 626-633.

[21] Guan-Zetic VG, Stehlik-Tomas V, Grba S, Lutilsky L, Kozlek D. Chromium uptake by Saccharomyces cerevisiae and isolation of glucose tolerance factor from yeast biomass. Journal of Biosciences 2001; 26 (2): 217-223.

[22] Pekmez M. Oksidatif stres uygulanmış Schızosaccharomyces Pombe'de moleküler çalışmalar. Yüksek Lisans Tezi, İstanbul Üniversitesi Fen Bilimleri Enstitüsü, 2004.

[23] Nikolai EP, Tatyana VL, Tatyana AK, Lowell PK. Carotenoids as scavengers of free radicals in a Fenton reaction: Antioxidants or pro-oxidants? Free Rad Bio And Med 2001; 31 (3): 398-404.

[24] Kireçci OA. Saccharomyces cerevisiae'nın Gelişme Ortamına İlave Edilen Ağır Metallerin (Mn, Mg, Cd, Fe) Bazı Biyokimyasal Parametrelere Etkileri. KSÜ Doğa Bil Derg 2017; 20 (3): 175-184.

[25] Thomas MJ. The role of free radicals and antioxidants. Critical Reviews in Food and Sci Nutrition 1995; 35 (1-2): 2139.

[26] Van-Der-Meulen JH, McArdle A, Jackson MJ, Faulkner JA. Contraction-induced injury to the extensor digitorum longus muscles of rats: the role of vitamin E. J Appl Physiol 1997; 83 (3): 817-823.

[27] Kaur G, Alam MS, Athar M. Cumene hydroperoxide debilitates macrophage physiology by inducing oxidative stres: Possible protection by $\alpha$-tocopherol. Chemico- Biological Interactions 2009; 179: 94-102.

[28] Sies H, Stahl W, Sundqust AR. Antioxidant function of vitamins. Vitamin E and C, betacarotene and other carotenoidsa. Ann N Y Acad Sci 1992; 669: 7-20.

[29] Acharya S, Acharya UR. In vivo lipid peroxidation responses of tissues in lead-induced Swiss mice. Ind Health 1997; 35: 542-544.

[30] Hancock RD, Galpin JR, Viola R. Biosynthesis of L-ascorbic acid (vitamin C) by Saccharomyces cerevisiae. FEMS Microbiology Letters 2000; 186: 245-250.

[31] Valko M, Morris H, Cronin MT. Metals, toxicity and oxidative stress. Curr Med Chem 2005; 12: 1161-1208.

[32] Lushchak VI. Oxidative stress as a component of transition metal toxicity in fish. In: Svensson, E.P. (Ed.), Aquatic Toxicology Research Focus. Nova Science Publishers Inc., Hauppauge, NY, USA (pp. 1-29), 2008.

[33] Gonzalez MJ, Miranda-Massari JR, Mora EM, Guzman A, Riordan NH, Riordan HD, Casciari JJ, Jackson JA, Roman Franco A. Orthomolecular oncology review: ascorbic acid and cancer 25 years later. Integrative Cancer Therapies 2005; 4: $32-44$.

[34] Büyükakyüz N, Altuğ T, Yaltırık M. Kanser proflaksisinde antioksidan maddelerden E vitamini ve selenyumun önemi. Diş Hekimliğinde Klinik Dergi 2000; 12: 136-139.

[35] Smirnova GV, Oktyabrsky ON. Glutathione in Bacteria. Biochemistry (Moscow) 2005; 70 (11): 1199-1211.

[36] Masip L, Veeravalli K, Georgiou G. The Many Faces of Glutathione in Bacteria. Antioxidants \& Redox Signaling 2006; $8(5-6): 753-762$.

[37] Stephen DWS, Jameison DJ. Glutathione is important antioxidant molecule in the yeast Saccharomyces cerevisiae. FEMS Microbiology Letters 1996; 141: 207-212. 
[38] Chai YC, Ashraf SS, Rokutan K, Johnston RB, Jr Thomas, JA. Sthiolation of individual human neutrophil proteins including actin by stimulation of the respiratory burst: evidence againist a role for glutathione disulfide. Arch Biochem Biophys 1994; 310: 273-281.

[39] Morel Y, Barauki R. Repression of gene expression by oxidative stres. Biochem J 1999; 342: 481-496.

[40] Costa V, Moradas-Ferreira P. Oxidative stress and signal transduction in Saccharomyces cerevisiae: insights into ageing, apoptosis and diseases. Molecular Aspects of Medicine 2001; 22: 217-246. 